\title{
A REVIEW ON AGENTS FOR THE TREATMENT OF LEPROSY INFECTION
}

\author{
MUHANAD MOHAMED HABIBALLA AHMED, ANURADHA, PANKAJ WADHWA*
}

Department of Pharmaceutical Sciences, Lovely Professional University, Phagwara, Punjab, India. Email: pankajwadhwa88@gmail.com Received: 25 November 2020, Revised and Accepted: 06 January 2021

\begin{abstract}
Leprosy is an ancient disease which is caused due to bacterial infection while curable but endures to be a substantial health problem in numerous parts across the world. It is an extremely contagious disease that is caused by any of 3 strains of bacteria such as Mycobacterium tuberculosis; Nontuberculous Mycobacterium; and Mycobacterium leprae. In several regions of Brazil, leprosy is a health issue which is still an endemic. Mainly skin, peripheral nerves, eyes, and mucosa of the upper respiratory tract are affected due to this chronic infection. As per the data shared by WHO across 159 countries globally, there were around 208,619 new leprosy cases reported. The global prevalence of leprosy is overcome with the aid of multidrug therapy which remains to be the chiefly targeted for treatment. The multidrug therapy gets attention as they show tremendous potential in fighting this disease. This review briefs about the different drugs and strategies which are used in treatment and superintendence of leprosy.
\end{abstract}

Keywords: Leprosy, Pathogenesis, Manifestations, Treatment, Ribonucleotide reductase.

(C) 2021 The Authors. Published by Innovare Academic Sciences Pvt Ltd. This is an open access article under the CC BY license (http://creativecommons.org/ licenses/by/4.0/) DOI: http://dx.doi.org/10.22159/ajpcr.2021v14i3.40373. Journal homepage: https://innovareacademics.in/journals/index.php/ajpcr

\section{INTRODUCTION}

Mycobacteria are slow-growing immobile Gram-positive bacteria with rod-shaped characteristics and usually classified into three types such as Mycobacterium tuberculosis; Nontuberculous Mycobacterium; and Mycobacterium leprae [1-6]. The disease leprosy or Hansen's disease which was discovered by Gerhard Henrik Armauer Hansen in 1873 is an old and ancient curable bacterial causing disease caused by $M$. leprae bacillus ( $M$. leprae). It produces chronic infection to humans and it mainly affects peripheral nervous systems and skin but may also get to sites such as eyes, mucus membrane, bone, testes along with many types of clinical phenotypes in the skin [7-10]. It is contagious and can be transmitted by coughs or even by contacting nasal fluids that are on the surface. Many reportedly observed that the human body can prevent infections but children are more at risk. Many countries such as India, Nepal, China, Japan, and Egypt have large numbers of leprosy infected patients. It is categorized into two types such as paucibacillary (PB) leprosy and multibacillary (MB) leprosy [11-18]. The initial one is characterized by one or a little hypo/hyperpigmented skin macules exhibiting loss of feeling (sensation, anesthesia) caused by inflammation of the peripheral nerve supply area. The second one is defined by generalized or diffuse skin involvement, peripheral nerve thickening under microscopic inspection, and has the potential to influence other organs, eyes, nose, testicles, and bone. The most advanced form of the disease is the nodular form of this condition. Other effects like multiple skin lesions without loss of sensation, plaques followed by dermis thickening as well as nasal congestion, and epistaxis are also associated with it. Here, we have summarized the characteristics differences between them in Table 1 [19-25].

\section{PATHOGENESIS OF LEPROSY}

The causative agent $M$. leprae is an acid-fast, Gram-positive obligate intracellular bacillus showing tropism in reticuloendothelial and peripheral system (especially Schwann cells) cells, The susceptible host will typically acquire species through the system or skin contact (between exudates of the skin lesions of a leprosy patient and another person's abraded skin), Just a little proportion of infected individuals show symptoms of the disease with a period starting from 6 months to 40 years or longer [26-30]. With its low pathogenicity condition, Bacilli migrate toward the neural tissue to the Schwann cells after entering the body. On the surface of Schwann cells, Tolllike receptors (such as -1 and 2 ) also play a big role in triggering the genes of apoptosis and which boosts the onset of nerve damage found in mild disease [31-34]. Usually, Bacilli start multiplying slowly (about 12-14 days for one bacterium to divide into two) within the cells and get rid of damaged cells and invade other unaffected cells, Till this stage individual remains free from signs and symptoms of leprosy, as bacilli multiply, bacterial load increases within the body, and infection is detected by the immune system, lymphocytes and histiocytic (macrophages) invade the infected tissue. At this time, clinical manifestation may appear as the involvement of nerves with impairment of sensation and/or pad [35-40]. If it is not diagnosed and treated within the early stages, further progress of the diseases is decided by the strength of the patient's immunologic response. Specific and effective cell-mediated immunity (CMI) provides protection and in this condition, it regulates the infection inside the body or generates leprosy PB type or if CMI is deficient then the disease spreads uncontrolled and produces MB leprosy with multiple system involvement. This may lead to invasion of the bloodstream which results in foci within the liver, spleen, adrenals, testicles, and bone marrow and excretion within the milk. In many reports, it was observed that lepromatous leprosy (MB leprosy) is more infectious than other types and has a poor prognosis [41-46]. The progress of the disease is also shown in Fig. 1.

The signs and symptoms for leprosy infection are moderate and slowly arising and are quite same to people that can present in syphilis, tetanus, and leptospirosis. The above are the primary symptoms of leprosy includes numbness, temperature as well as contact lost sensations, needles sensation, Ache (joint), deep pressure stimuli are weakened or missing, nerve injury, ulcers, rashes, lesions on skin (pigmented areas on the skin which result in losing the skin color), losing of eyebrows, disappearing of facial features, etc. [47-50].

\section{TREATMENT AVAILABLE FOR LEPROSY}

Antibiotics cure the bulk of cases of leprosy and the prescription of antibiotics with suitable dosage and period of administration depends upon the variety of the disease [51-55]. Mainly three drugs such as clofazimine (compound 1), rifampicin (compound 2), and dapsone (compound 3) are generally prescribed to treat leprosy infections [56-58]. Health practitioners typically prescribe antibiotics 
for a minimum of 6-12 months or longer to treat the illness. Recently, the WHO has proposed that single-dose treatment of patients with only 1 skin lesion with rifampicin, minocycline (Minocin), or ofloxacin (Floxin) is successful. Studies on other antibiotics are continuing [54,59-61]. Several medical practitioners have used steroid treatments to cut back discomfort and acute leprosy inflammation; however, clinical trials have found no clear long-term effects on nerve damage. The role of surgery within the treatment of leprosy exists after a patient has undergone medical therapy (antibiotics) with negative skin (no detectable acid-fast bacilli) and is typically required only in advanced cases [62-66]. The illness is treated with a mix of antibiotics like using the combination of rifampicin dapsone, and clofazimine to avoid the assembly of antibiotic resistance by bacteria, which could otherwise arise due to the amount of treatment. The disease treatment typically lasts between 1 and 2 years. The condition will be reversed provided the therapy is done as specified. Apart from this many natural plant remedies are also available which include neem paste, hydrocotyle asiatica, and frankincense aromatherapy, respectively [67-74]. Patients should negotiate all home remedies with their practitioner before utilizing such methods.

Many reportssuggested that the emergence of drug-resistantleprosy is a very critical situation in the successful treatment of leprosy infection. To tackle,

Table 1: Difference between MB and paucibacillary

\begin{tabular}{lll}
\hline Characteristics & PB & MB leprosy \\
\hline Skin lesions & $\bullet$ 1-5 lesions & $\bullet>5$ lesions \\
& $\bullet$ Asymmetrical & $\bullet$ Toward symmetrical \\
& $\bullet$ Definite loss of & $\bullet$ No loss of sensation \\
& sensation & \\
Nerve lesions & Only one nerve & Two or more nerve are \\
& Is involved & involved \\
\hline
\end{tabular}

PB: Paucibacillary, MB: Multibacillary this the research is ongoing to inhibit the enzyme ribonucleotide reductase (RNR) because of its involvement in the biosynthesis of nucleotides [49,7578]. Many reports also suggested that the enzyme dihydropteroate synthase (DHPS) is also one of the important enzymatic targets $[79,80]$. Hence, we thought to include the details of the agent developed for inhibiting the RNR and DHPS action. In the next section, we will discuss about those inhibitors and their structures as mentioned in Table 2 .

In the year 2019, Ertas et al. reported the synthesis and evaluation of 24 thiosemicarbazones derivatives against RNR enzyme. Their study results reported that two compounds (compound 4-5) have shown significantly better activity than reference compound metisazone. Further, their cytotoxic effects were also analyzed using MCF7 (human breast adenocarcinoma) and HEK293 (human embryonic kidney) cell lines, and these three compounds were shown a selective effect on the MCF7 and HEK293 cell lines, damaging and terminating more cancer cells than cisplatin as standard [81]. Misko and their group members have reported that enzyme RNR is one kind of essential anti-cancer target due to their involvement in the rate-limiting step of dNTP synthesis. They have further evaluated the class of naphthyl salicylic acyl hydrazonebased inhibitor (NSAH) and reported that (compound 6) have shown significant inhibitory action against Panc1 carcinoma cell line with an $\mathrm{IC}_{50}$ of $0.393 \mathrm{mM}$ through binding to the catalytic site. They have further modified the NSAH derivatives through incorporating cyclic and polar groups instead of naphthyl moiety that was found to occupy the phosphate-binding pocket within the C-site [82]. Crona et al. have evaluated the activity of anti-proliferative molecules for inhibiting the RNR catalyzed reduction of ribonucleotides to deoxyribonucleotides. Their study results concluded that NSC73735 (compound 7) can hinder the oligomerization of the RNR subunits of mammals as well as interruption of HL- 60 cell culture in the cell cycle and can be used as a possible lead for further development [83]. Nasr et al. evaluated a series of acrylamide derivatives bearing the sulfasalazine moiety against

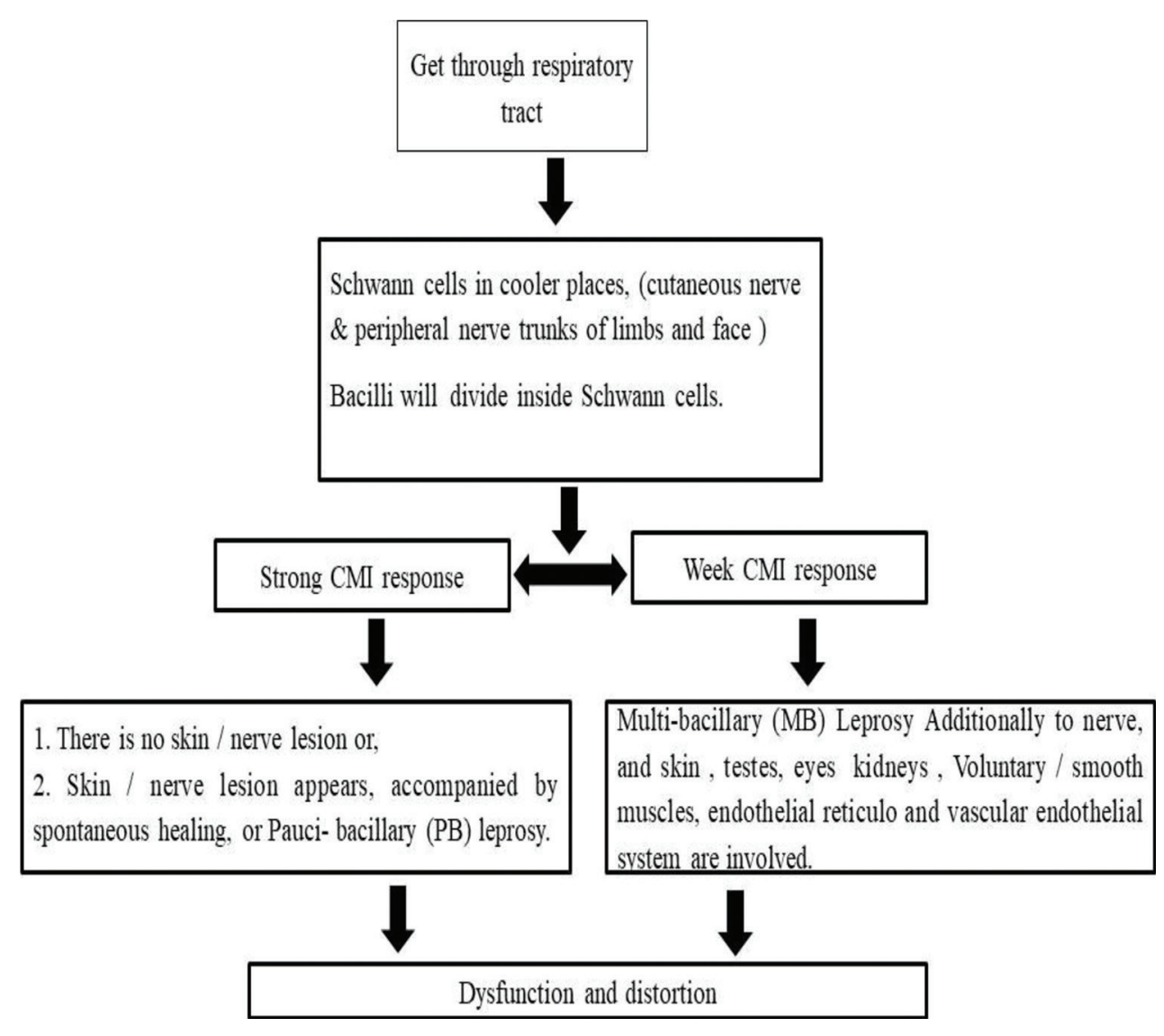

Fig. 1: Brief representation of leprosy pathogenesis 
Table 2: Representing the structures of developed for leprosy infection<smiles>CC(C)/N=c1\cc2n(-c3ccc(Cl)cc3)c3ccccc3nc-2cc1Nc1ccc(Cl)cc1</smiles><smiles>O=S(=O)(c1ccccc1)c1ccccc1</smiles>

Compound 3<smiles>COc1ccc(-c2ccsc2)c(/C=N/NC(=O)c2ccccc2O)c1O</smiles>

Compound 5<smiles>COc1cc(-c2ccc(Nc3ccccc3C(=O)O)c(OC)c2)ccc1Nc1ccccc1C(=O)O</smiles>

Compound 7<smiles>C=CCN/C(SCC)=C(/C#N)C(=O)Nc1ccc(S(=O)(=O)Nc2onc(C)c2C)cc1</smiles>

Compound 9

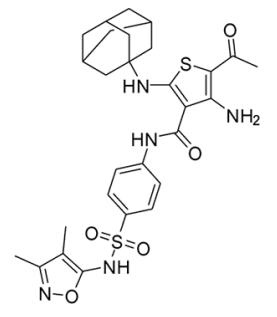

Compound 11

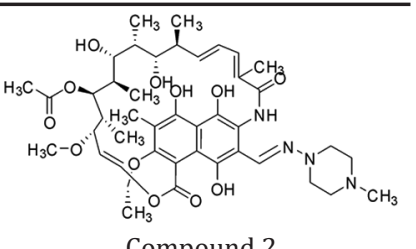

Compound 2<smiles>CNC(=S)N/N=C(\C)c1sc(-c2ccccn2)nc1C</smiles>

Compound 4<smiles>COc1ccc(-c2ccsc2)c(/C=N/NC(=O)c2ccccc2O)c1O</smiles><smiles>CCN/C(SCC)=C(/C#N)C(=O)Nc1ccc(S(=O)O)cc1</smiles>

Compound 8<smiles>CC(=O)c1sc(NC23CC4CC(CC(C4)C2)C3)c(C(=O)Nc2ccc(S(=O)(=O)Nc3onc(C)c3C)cc2)c1N</smiles>

Compound 10<smiles>[R]S(=O)(=O)c1ccc(NCc2cnc3nc(N)[nH]c(=O)c3n2)cc1</smiles>

Compound 12
DHPS. Their study results showed that two analogs (compound 8-9) have been shown significant action in opposition to Bacillus subtilis. Both compounds also displayed two and three folds the potency of amphotericin B against Syncephalastrum racemosum, respectively [84]. The earlier same group also reported that the anti-bacterial activity of $28 \mathrm{~N}$-substituted sulfisoxazole analogs and reported that two compounds thiophene $\mathbf{1 0}$ and 6 thioglucosylpyridone $\mathbf{1 1}$ have shown significant inhibition of Escherichia coli and B. subtilis at $\mathrm{IC}_{50}$ value of $0.007 \mu \mathrm{g} / \mathrm{ml}$, respectively [85]. In the same year, almost eight pterin sulfonamide conjugates (general structure represented as compound 12) were prepared and evaluated. All conjugates have been shown significant inhibition of DHPS competitively due to catalysis action of the present pyrophosphate group which is crucial to catalysis and is thought to market an ordering of the DHPS site [86].

\section{CONCLUSION}

M. leprae is the causative agent for leprosy infection. In the year 1981 after the launching of multidrug therapy followed by the development of fixed duration therapy in the year 1992, revolutionized the treatment process. Many types of newly developed agents have been developed through showing inhibition of enzymes RNR and DHPS against leprosy infection. In the present review, the data related to those things are reported. This will help the readers in the successful development of new agents against bacterial infections. 


\section{AUTHORS' CONTRIBUTIONS}

All the authors were involved in the collection, processing of data information, and preparation of the manuscript.

\section{CONFLICTS OF INTEREST}

The authors declare no conflicts of interest in any way.

\section{FUNDING}

Nil.

\section{REFERENCES}

1. Belachew WA, Naafs B. Position statement: LEPROSY: Diagnosis, treatment and follow-up. J Eur Acad Dermatol Venereol 2019;33:1205-13.

2. Agrawal A. Clinical management of leprosy reactions. Infect Dis Clin Pract 2010;18:230

3. Antunes DE, Araujo S, Ferreira GP, Cunha AC, Costa AV, Gonçalves MA, et al. Identification of clinical, epidemiological and laboratory risk factors for leprosy reactions during and after multidrug therapy. Mem Inst Oswaldo Cruz 2013;108:901-8.

4. Avanzi C, Singh P, Truman RW, Suffys PN. Molecular epidemiology of leprosy: An update. Infect Genet Evol 2020;86:104581.

5. Bennett BH, Parker DL, Robson M. Leprosy: Steps along the journey of eradication. Public Health Rep 2008;123:198-205.

6. Bharadwaj M. Revalidation of various clinical criteria for the classification of leprosy-a clinic-pathological study. Lepr Rev 2012;83:354-62.

7. Tortoli E. Microbiological features and clinical relevance of new species of the genus Mycobacterium. Clin Microbiol Rev 2014;27:727-52.

8. Bhat RM, Prakash C. Leprosy: An overview of pathophysiology. Interdiscip Perspect Infect Dis 2012;2012:181089.

9. Bhide AA, Khemani UN, Kamath RR, Vaidyanathan V, Ponathil AP, Kura MM. An alternative hepatosafe treatment in leprosy. Indian J Drugs Dermatol 2016;2:33.

10. Bratschi MW, Steinmann P, Wickenden A, Gillis TP. Current knowledge on Mycobacterium leprae transmission: A systematic literature review. Lepr Rev 2015;86:142-55.

11. Bremner JB, Ambrus JI, Samosorn S. Dual action-based approaches to antibacterial agents. Curr Med Chem 2007;4:1459-77.

12. Campbell EA, Korzheva N, Mustaev A, Murakami K, Nair S, Goldfarb A, et al. Structural mechanism for rifampicin inhibition of bacterial RNA polymerase. Cell 2001;104:901-2.

13. Cavazzuti A, Paglietti G, Hunter WN, Gamarro F, Piras S, Loriga M, et al. Discovery of potent pteridine reductase inhibitors to guide antiparasite drug development. Proc Natl Acad Sci USA 2008;105:1448-53.

14. Cortela DC, de Souza AL Jr., Virmond MC, Ignotti E. Inflammatory mediators of leprosy reactional episodes and dental infections: A systematic review. Mediators Inflamm 2015;2015:548540.

15. Costa PD, Fraga LR, Kowalski TW, Daxbacher EL, Schuler-Faccini L, Vianna FS. Erythema nodosum leprosum: Update and challenges on the treatment of a neglected condition. Acta Trop 2018;183:134-41.

16. Dacso MM, Jacobson RR, Scollard DM, Stryjewska BM, Prestigiacomo JF. Evaluation of multi-drug therapy for leprosy in the United States using daily rifampin. South Med J 2011;104:689-94.

17. de Souza Aarão TL, Esteves NR, Esteves N, de Miranda Soares LP, da Silva Pinto D, Fuzii HT, et al. Relationship between growth factors and its implication in the pathogenesis of leprosy. Microb Pathog 2014:77:66-72.

18. Degang Y, Akama T, Hara T, Tanigawa K, Ishido Y, Gidoh M, et al. Clofazimine modulates the expression of lipid metabolism proteins in Mycobacterium leprae-infected macrophages. PLoS Negl Trop Dis 2012;6:e1936.

19. El Idrissi NB, Das PK, Fluiter K, Rosa PS, Vreijling J, Troost D, et al. Leprae components induce nerve damage by complement activation: Identification of lipoarabinomannan as the dominant complement activator. Acta Neuropathol 2015;129:653-67.

20. Fischer M. Leprosy-an overview of clinical features, diagnosis, and treatment. J Dtsch Dermatol Ges 2017;15:801-27.

21. Gaschignard J, Grant AV, Thuc NV, Orlova M, Cobat A, Huong NT, et al. Pauci-and multibacillary leprosy: Two Distinct, genetically neglected diseases. PLoS Negl Trop Dis 2016;10:e0004345.

22. Gautam VP. Treatment of leprosy in India. J Postgrad Med 2009;55:220-4.

23. Gelber RH, Grosset J. The chemotherapy of leprosy: An interpretive history. Lepr Rev 2012;83:221-40.
24. Graham A, Furlong S, Margoles LM, Owusu K, Franco-Paredes C. Clinical management of leprosy reactions. Infect Dis Clin Pract 2010;18:235-8.

25. Gupta SK. Histoid leprosy: A review of the literature. Int J Dermatol 2015;54:1283-8

26. Parkash O. Classification of leprosy into multibacillary and paucibacillary groups: An analysis. FEMS Immunol Med Microbiol 2009;55:1-5

27. Aarao TL, de Sousa JR, Falcao AS, Falcao LF, Quaresma JA. Nerve growth factor and pathogenesis of leprosy: Review and update. Front Immunol 2018;9:939.

28. Polycarpou A, Walker SL, Lockwood DN. New findings in the pathogenesis of leprosy and implications for the management of leprosy. Curr Opin Infect Dis 2013;26:413-9.

29. Gutierrez MC, Supply P, Brosch R. Pathogenomics of mycobacteria. In: Microbial Pathogenomics. Vol. 6. Germany: Karger; 2009. p. 198-210.

30. Hevener KE, Yun MK, Qi J, Kerr ID, Babaoglu K, Hurdle JG, Lee RE. Structural studies of pterin-based inhibitors of dihydropteroate synthase. J Med Chem 2010;53:166-77.

31. Honap TP, Pfister LA, Housman G, Mills S, Tarara RP, Suzuki K, et al. Mycobacterium leprae genomes from naturally infected nonhuman primates. PLoS Negl Trop Dis 2018;12:e0006190.

32. Hwang TJ, Dotsenko S, Jafarov A, Weyer K, Falzon D, Lunte K, et al. Safety and availability of clofazimine in the treatment of multidrug and extensively drug-resistant tuberculosis: Analysis of published guidance and meta-analysis of cohort studies. BMJ Open 2014;4:e004143.

33. Ishii N. Recent advances in the treatment of leprosy. Dermatol Online J 2003;9:5.

34. Jyothi P, Riyaz N, Nandakumar G, Binitha MP. A study of oxidative stress in paucibacillary and multibacillary leprosy. Indian J Dermatol Venereol Leprol 2008;74:80.

35. Kahawita IP, Lockwood DN. Towards understanding the pathology of erythema nodosum leprosum. Trans R Soc Trop Med Hyg 2008; 102:329-37.

36. Kamath S, Vaccaro SA, Rea TH, Ochoa MT. Recognizing and managing the immunologic reactions in leprosy. J Am Acad Dermatol 2014;71:795-803

37. Pfyffer GE. Mycobacterium: General characteristics, laboratory detection, and staining procedures. In: Manual of Clinical Microbiology. Washington, DC: ASM Press; 2015. p. 536-69.

38. Prasad PV, Kaviarasan PK. Leprosy therapy, past and present: Can we hope to eliminate it. Indian J Dermatol 2010;55:316-24.

39. Prasad PV, Babu A, Kaviarasan PK, Viswanathan P, Tippoo R. MDTMB therapy in paucibacillary leprosy: A clinicopathological assessment. Indian J Dermatol Venereol Leprol 2005;71:242-5.

40. Rastogi N, Legrand E, Sola C. The mycobacteria: An introduction to nomenclature and pathogenesis. Rev Sci Tech 2001;20:21-54.

41. Reibel F, Cambau E, Aubry A. Update on the epidemiology, diagnosis, and treatment of leprosy. Med Mal Infect 2015;45:383-93.

42. Ren YR, Pan F, Parvez S, Fleig A, Chong CR, Xu J, et al. Clofazimine inhibits human Kv1. 3 potassium channel by perturbing calcium oscillation in T lymphocytes. PLoS One 2008;3:e4009.

43. Rodrigues LC, Lockwood DN. Leprosy now: Epidemiology, progress, challenges, and research gaps. Lancet Infect Dis 2011;11:464-70.

44. Rook GA, Hamelmann E, Brunet LR. Mycobacteria and allergies. Immunobiology 2007;212:461-73.

45. Sarode G, Sarode S, Anand R, Patil S, Jafer M, Baeshen H, et al. Epidemiological aspects of leprosy. Dis Mon 2020;66:100899.

46. Scollard DM. Chemotherapy of leprosy has changed (almost) everything. Lepr Rev 2012;83:245-6.

47. Scollard DM. The biology of nerve injury in leprosy. Lepr Rev 2008;79:242-53

48. Eichelmann K, Gonzalez SG, Salas-Alanis JC, Ocampo-Candiani J. Leprosy. An update: Definition, pathogenesis, classification, diagnosis, and treatment. Actas Dermosifiliogr 2013;104:554-63.

49. Worobec SM. Treatment of leprosy/Hansen's disease in the early $21^{\text {st }}$ century. Dermatol Ther 2009;22:518-37.

50. Kumar B, Dogra S, Kaur I. Epidemiological characteristics of leprosy reactions: 15 years experience from North Indial. Int J Lepr Other Mycobact Dis 2004;72:125-33.

51. Lastória JC, de Abreu MA. Leprosy: Review of the epidemiological, clinical, and etiopathogenic aspects-Part 1. An Bras Dermatol 2014;89:205-18.

52. Lockwood DN, Kumar B. Treatment of leprosy. BMJ 2004;328:1447-8.

53. Lockwood DN, Saunderson PR. Nerve damage in leprosy: A continuing challenge to scientists, clinicians and service providers. Int Health 2012;4:77-85. 
54. Maymone MB, Venkatesh S, Laughter M, Abdat R, Hugh J, Dacso MM, et al. Leprosy: Treatment and management of complications. J Am Acad Dermatol 2020;83:17-30.

55. Monot M, Honoré N, Garnier T, Araoz R, Coppée JY, Lacroix C, et al. On the origin of leprosy. Science 2005;308:1040-2.

56. Moschella SL. An update on the diagnosis and treatment of leprosy. J Am Acad Dermatol 2004;51:417-26.

57. Mungroo MR, Khan NA, Siddiqui R. Mycobacterium leprae: Pathogenesis, diagnosis, and treatment options. Microb Pathog 2020; $149: 104475$

58. Naafs B. Leprosy after the year 2000. Trop Med Int Health 2000;5:400-3.

59. Narang T, Dogra S. Minocycline in leprosy patients with recent onset clinical nerve function impairment. Dermatol Ther 2017;30:e12404.

60. Kar HK, Gupta R. Treatment of leprosy. Clin Dermatol 2015;33:55-65.

61. Katoch VM. Advances in the diagnosis and treatment of leprosy. Expert Rev Mol Med 2002;4:1-14.

62. Ooi WW, Srinivasan J. Leprosy and the peripheral nervous system: Basic and clinical aspects. Muscle Nerve 2004;30:393-409.

63. Pai VV. Role of clofazimine in management of reactions in leprosy: A brief overview. Indian J Drugs Dermatol 2015;1:12.

64. Pai VV, Ganapati R, Rao R. Development and evolution of WHO MDT and newer treatment regimens. In: IAL Textbook of Leprosy. New Delhi: Jaypee Brothers Medical Publishers Pvt. Ltd.; 2010. p. 353-67.

65. Qi J, Virga KG, Das S, Zhao Y, Yun MK, White SW, et al. Synthesis of bi-substrate state mimics of dihydropteroate synthase as potential inhibitors and molecular probes. Bioorg Med Chem 2011;19:1298-305.

66. Rambukkana A. Molecular basis for the peripheral nerve predilection of Mycobacterium leprae. Curr Opin Microbiol 2001;4:21-7.

67. Rao PN, Jain S. Newer management options in leprosy. Indian J Dermatol 2013;58:6-11.

68. Scollard DM, Adams LB, Gillis TP, Krahenbuhl JL, Truman RW, Williams DL. The continuing challenges of leprosy. Clin Microbiol Rev 2006;19:338-81.

69. Scollard DM, Stryjewska BM, Prestigiacomo JF, Gillis TP, WaguespackLaBiche J. Hansen's disease (leprosy) complicated by secondary mycobacterial infection. J Am Acad Dermatol 2011;64:593-6.

70. Sehgal VN, Sardana K, Dogra S. The imperatives of leprosy treatment in the pre-and post-global leprosy elimination era: Appraisal of changing the scenario to current status. J Dermatolog treat 2008;19:82-91.

71. Setia MS, Shinde SS, Jerajani HR, Boivin JF. Is there a role for rifampicin, ofloxacin and minocycline (ROM) therapy in the treatment of leprosy? Systematic review and meta-analysis. Trop Med Int Health
2011;16:1541-51.

72. Simon M, Scherlock J, Duthie MS, de Jesus AR. Clinical, immunological, and genetic aspects in leprosy. Drug Dev Res 2011;72:509-27.

73. Swaminathan S, Rekha VB. Drugs used in tuberculosis and leprosy. In: Side Effects of Drugs Annual. Vol. 32. Netherlands: Elsevier; 2010. p. 555-69.

74. Talhari C, Talhari S, Penna GO. Clinical aspects of leprosy. Clin Dermatol 2015;33:26-37

75. Tortoli E. The new mycobacteria: An update. FEMS Immunol Med Microbiol 2006;48:159-78.

76. Walker SL, Lockwood DN. Leprosy Type 1 (reversal) reactions and their management. Lepr Rev 2008;79:372-86.

77. White C, Franco-Paredes C. Leprosy in the $21^{\text {st }}$ century. Clin Microbiol Rev 2015;28:80-94.

78. Wilder-Smith EP, van Brakel WH. Nerve damage in leprosy and its management. Nat Clin Pract Neurol 2008;4:656-63.

79. Mohanty PS, Bansal AK, Naaz F, Gupta UD, Dwivedi VD, Yadava U. Ribonucleotide reductase as a drug target against drug resistance Mycobacterium leprae: A molecular docking study. Infect Genet Evol 2018;60:58-65.

80. Maladan Y, Krismawati H, Hutapea HM, Oktavian A, Fatimah R. A new Mycobacterium leprae dihydropteroate synthase variant (V39I) from Papua, Indonesia. Heliyon 2019;5:e01279.

81. Ertas M, Sahin Z, Bulbul EF, Bender C, Biltekin SN, Berk B, et al. Potent ribonucleotide reductase inhibitors: Thiazole-containing thiosemicarbazone derivatives. Arch Pharm 2019;352:1900033.

82. Misko TA, Liu YT, Harris ME, Oleinick NL, Pink J, Lee HY, et al. Structure-guided design of anti-cancer ribonucleotide reductase inhibitors. J Enzyme Inhib Med Chem 2019;34:438-50.

83. Crona M, Codo P, Jonna VR, Hofer A, Fernandes AP, Tholander F. A ribonucleotide reductase inhibitor with deoxyribonucleoside-reversible cytotoxicity. Mol Oncol 2016;10:1375-86.

84. Nasr T, Bondock S, Ibrahim TM, Fayad W, Ibrahim AB, AbdelAziz NA, et al. New acrylamide-sulfisoxazole conjugates as dihydropteroate synthase inhibitors. Bioorg Med Chem 2020;28:115444.

85. Nasr T, Bondock S, Eid S. Design, synthesis, antimicrobial evaluation and molecular docking studies of some new thiophene, pyrazole and pyridone derivatives bearing sulfisoxazole moiety. Eur J Med Chem 2014;84:491-504.

86. Zhao Y, Shadrick WR, Wallace MJ, Wu Y, Griffith EC, Qi J, et al. Pterin-sulfa conjugates as dihydropteroate synthase inhibitors and antibacterial agents. Bioorg Med Chem Lett 2016;26:3950-4. 